therefore feel it our duty to state that we have no confidence whatsoever in the present Minister of Health, and wish to alert the profession to this new tendency to subordinate the doctor's clinical judgment to the irresponsible dictates of the lay administrator.-We are, etc.,

D. O'Driscoll, H SOUThWORTH, T. J. BuRKe, F. C. Reidy, B. D. Mallick, A. C. Newman, J. A. McCraith, J. Tudor, J. Kyle, N. M. Greeves, J. D. Condon, E. ISHERWOOD, C. M. BRADley, I. E. Douglas, A. H. Duncan, F. Livesey, R. G. ROONEY, H. T. CaNK, R. V. RhODA, C. L. HOLden, P. Zimmerman, J. A. Noblett, W. BRock, P. G. Jones, A. R. MERRILl, A. Robinson, A. WispiansKy, L. M. C. DUTHIE, I. R. Duthie, H. Harrison, A. H. Gregson, J. A. Sellars, J. Carter, T. A. I. McQuay, P. N: Rampal, J. J. Searson, J. J. O'Callaghan, E. L. Carter, A. Hargreaves, J. B. Leigh, J. W. Lyall, J. L. Johnston, H. Hardman, R. Pendlebury, D. Kelleher, A. C. Smerdon. Blackburn

\section{Assistants in General Practice}

SIR,-Dr. G. E. Langley (Supplement, February 5, p. 42) has spoken for many of us. At the moment there are too many assistants, the number being given as about 1,500, which I take to mean assistants pure and simple (an apt phrase). We are the displaced persons of the Health Service. Presumably this situation will improve after 1958, but I believe till then we should adopt the best of Dr. Langley's suggestions-that is, that as an interim measure registrars should be given better salaries, enabling them to support a wife and stay in hospitals without being forced to leave early because of financial pressure. Meanwhile, as an indefinite and ever-changing body, we have little say. Unlike the railwaymen (or even the Sabine women) we cannot down tools. We may query the sense of the large university classes, or watch the exploitation of our kind, but I personally feel it is unlikely we shall ever have enough political or professional influence to alter our conditions.

To end on a lighter note, as I intend to sign this, it is only fair to my employers to say that I am neither overworked, underpaid, nor disgruntled, but consider myself lucky. I am an assistant without view, and it would be interesting to hear a few figures from people in my position. In 18 months $I$ have made seven or eight applications, been interviewed once (out of 120 applicants), and am still hopeful of finding paradise. This to my mind is in the country or a country town midway between an Auxiliary Air Force squadron, a motor racing circuit, a good book-shop, and a comfortable pub or hotel.-I am, etc.,

Wisbech, Cambs. G. R. C. D. Gibson.

\section{Association Notices}

\section{Diary of Central Meetings}

MaRCH

8 Tues. Constitution Committee, 11 a m.

10 Thurs. Psychological Medicine Group Committee, 2 p.m. 11 Fri. Joint Meeting of Coroners and Medical Witnesses Subcommittees, Private Practice Committee, 2.30 p.m. (Change of date and time.)

16 Wed. Occupational Health Committee, 10 a.m

17 Thurs. Ethical Review Subcommittee, Central Ethical Committee, 2 p.m.

17 Thurs. Charities Committee, 2.15 p.m.

23 Wed. Tuberculosis and Diseases of the Chest Group Committee, 2 p.m.

24 Thurs. Central Consultants and Specialists Committee,

30 Wed. Evidence Committee on Divine Healing, 10 a.m

30 Wed. Committee re Remuneration Policy, 2 p.m.

31 Thurs. Conference of Honorary Secretaries of Divisions and Branches, $10.30 \mathrm{a} . \mathrm{m}$.

\section{Branch and Division Meetings to be Held}

Burton-on-Trent Division.-At Bretby Golf Club, Ashby Road, Burton-on-Trent, Wednesday, March 9, 7.45 p.m., dinner. Annual B.M.A. Lecture by Mr. N. R. Barrett: "Indications for Cardiac Surgery."
City Division.-At Committee Room C, B.M.A. House, Tavistock Square, London, W.C. Tuesday, March 8 8.30 p.m., meeting. Mr. D. W. C. Northfield : "A G.P.'s Problems as Seen by a Neurological Surgeon."

COVENTRY DIVISION.-At Gymnasium, Coventry and Warwickshire Hospital, Wednesday, March 9, 8.30 p.m., meeting. Lecture by Dr. K. Sicher: "Applications and Results in the Treatment of Radiotherapy.'

Croydon Division.-At 43, Wellesley Road, Croydon, Tuesday, March 8, 8.30 p.m., general meeting. Address by Dr. F. E. Camps : "Medical Aspects on Detection of Crime."

DARTFORD DIVISION.-At Royal Clarendon Hotel, Gravesend, Wednesday, March 9, 8 for 8.15 p.m., annual dinner.

Dumfries AND Galloway Division.-Sunday, March 13, Pro-

fessor L. J. Davis: "Bronchitis and Emphysema."

East Herts Division.-At Hertford County Hospital, Tuesday, March 8, 8.30 p.m., meeting. Medical films.

EAST KENT Division.-At Chez Laurie Restaurant, Thanet Way, Herne Bay, Thursday, March 10, 7.30 p.m., dinner ; the Rectum and Anal Canal."

Enfield and Potters Bar Division.-At Chase Farm Hospital, The Ridgeway, Enfield, Wednesday, March 9, 8.15 for 8.45 p.m. meeting. Films : (1) "Relief of Pain in Childbirth"; (2) "The Conjoined Twins of Kano." Members of the North Middlesex and East Herts Divisions and nurses and student nurses in the area are invited.

FinCHLEY Division.-At Finchley Memorial Hospital, Granville Road, N. Finchley, N., Tuesday, March 8, 8.30 for 9 p.m., meeting. Talk by Mr. V. J. Downie: "The Virtues of Going to meeting."

FunNESS Division.-At Duke of Edinburgh Hotel, Barrow-inFurness, Friday, March 11, 7.30 for 8 p.m., annual dinner Principal speakers, Sir Ian Fraser, who will propose the toast of the B.M.A., and Dr. D. P. Stevenson (Deputy Secretary, B.M.A.), who will reply.

GUILDFord Division.-At Royal Surrey County Hospital, Guildford, Thursday, March 10, 8.30 p.m., meeting. Lecture by Dr. W. G. Oakley: " Modern Treatment of Diabetes."

Hampstead Division.-At New End Hospital, Hampstead, N.W., Tuesday, March 8, 8.30 p.m.,, meeting. Discussion: "Present-day Views on Thyroid Disease." Speakers, Dr. Rosalin Pitt-Rivers, Ph.D., F.R.S., Mr. J. E. Piercy, and Dr. W. R. Trotter.

Hendon Division.-At Hendon Hall Hotel, London, N.W., Tuesday, March 8, 8.45 p.m., meeting. Dr. W. E. Snell: "The Changing Scene in Tuberculosis."

KENSINGTON AND HaMMERSMITH Division.-At St. Charles's Hospital, Ladbroke Grove, London, W., Friday, March 11, 3.30 for 4 p.m., clinical meeting.

Kingston-ON-THAMES Division.-At Kingston Hospital (Nurses' Home), Tuesday, March 8, 8 p.m., meeting. General practitioners' debate: (a) "Blood Pressure"; $(b)$ "Is Penicillin Abused in General Practice ?"; (c) "Is the Home the Ideal Place to Have a Baby ?"; $(d)$ "The Common Cold and Influenza."

LAMBETH aND Southwark Division.-At Brockwell Primary School, Tulse Hill, London, S.W., Thursday, March 10, 8.15 p.m meeting. Film by Professor Ian Aird: "Conjoined Twins of Kano" and also his extra slides of still photographs. Mr. Selwyn Taylor will talk about the film and operation. Nurses and health visitors are invited

LANCASTER Division.-At Midland Hotel, Morecambe, Saturday, March $12,7.30$ for 8 p.m., annual dinner.

Leigh Division.-At Courts Hotel, Church Street, Leigh, Tuesday, March 8, 8.30 p.m., meeting. Address by Dr. E. E. Prebble: "Non-specific Urethritis."

ReIgate Division.-At Redhill County Hospital, Tuesday, March 8, 8.30 p.m., meeting. Annual B.M.A. Lecture by Professor

J. Chassar Moir: "Immediate Hazards of Childbirth."

SCarborough Division.-At Scarborough Hospital, Thursday, March 10, 8.30 p.m. meeting. Lecture by Professor R. E. Tunbridge : "Rehabilitation" (illustrated with lantern slides).

SOUTH BEDFORDSHIRE DIVISION.-At Luton and Dunstable Hospital, Friday, March 11, 9 p.m., meeting. Annual B.M.A. Lecture by Sir Heneage Ogilvie : "Pitfalls in Surgical Diagnosis." Tunbridge Wells Division.-At Kent and Sussex Hospital, Tunbridge Wells, Tuesday, March 8, 8.30 p.m., meeting. Dr. E. A Bennet: "Treatment in the Neuroses""

WillesDen Division.-At Wykeham School, Aboyne Road, Neasden, N.W., Thursday, March 10, 8 p.m., public meeting on Air Pollution." To be addressed by Dr. Horace Joules, Dr. S. Leff, Mr. R. S. Forster, and Councillor S. C. Piddington.

\section{S.H.M.O. Meeting}

There will be a meeting of Senior Hospital Medical Officers in the North-west Metropolitan Region on Saturday, March 12, at 3 p.m. at B.M.A. House, Tavistock Square, London, W.C.

Correction.-In the answer headed "Vaccination Certificates" under "Questions Answered" (Supplement, February 12, p. 47) it should have been added that T.A.B. vaccine for prophylactic injection may be prescribed on form E.C. 10 . 